\title{
Changing Sugar Consumption Pattern in Pakistan and Increasing Sugar Industry's Profitability
}

\author{
Imran Umer Chhapra* \\ KASB Institute of Technology (KASBIT) \\ Asim Mashkoor* \\ Institute of Business and Technology (IBT) \\ Nadeem A. Syed* \\ FAST Business School, National University, Karachi Campus
}

\begin{abstract} Purpose- Major aim of this study was to evaluate the impact of price hike and
purchasing power on sugar consumption pattern of individuals in Pakistan. The constant rising prices of food commodities including sugar, and the sugar crises the country mostly is seen caught into prompted researcher to conduct this study. Methodology/sample- The study involved use of questionnaires filled by 240 respondents and financial data of three sugar mills for the period of 2010-11 for financial analysis. The respondent individuals belonged to different age groups, social classes and areas of residence. To analyze the data, Regression, ANOVA and Correlation tests were applied. Data from three different sugar mills from three different provinces of Pakistan was also collected and financial analysis of their annual reports was conducted to determine their growing profits. Findings- The analysis and comparative results clearly suggested that individuals in Pakistan have decreased their sugar consumption due to increasing prices, while sugar mills are earning huge profits. It was also concluded that higher profits earned by the sugar mills was due to artificial shortage created by cartel making by the sugar mill owners in Pakistan.

Practical Implications- The outcomes of the research might help the corporate decision makers, government policy formulators and other related quarters to understand the impact of rising prices of commodities in Pakistan and to understand the overall dynamics and mechanism of sugar sector in Pakistan.
\end{abstract}

Keywords : Consumption, Rising prices, Sugar sector, High profit

* The material presented by the author does not necessarily portray the viewpoint of the editors and the management of the Institute of Business \& Technology (IBT) or KASB Institute of Technology (KASBIT) and FAST Business School, National University, Karachi.

* Imran Umer Chhapra : imran_js@yahoo.com

* Asim Mashkoor :

* Nadeem A. Syed : nadeem.syed@nu.edu.pk

C JMSS is published by the Institute of Business and Technology (IBT). Main Ibrahim Hydri Road, Korangi Creek, Karachi-75190, Pakistan. 


\section{INTRODUCTION \& AIM OF STUDY}

Pakistan is the $6 \mathrm{t}^{\mathrm{h}}$ largest country in the world in terms of area under sugarcane cultivation. For sugar production, sugarcane is considered to be the primary raw material. In Pakistan, sugarcane cultivation is increasing constantly compared to any other major crop of the country. Approximately one million hectares land is currently used as cultivation field for sugar in Pakistan indicating importance of sugarcane for Pakistan's economy.

Table 1

Top 10 World's Sugarcane Producers (Raw value in million metric tonnes)

\begin{tabular}{|c|l|c|}
\hline 1 & Brazil & 39.45 \\
\hline 2 & India & 21.15 \\
\hline 3 & China & 10.57 \\
\hline 4 & Thailand & 6.77 \\
\hline 5 & Mexico & 5.08 \\
\hline $\mathbf{6}$ & Pakistan & $\mathbf{3 . 8 5}$ \\
\hline 7 & Australia & 3.63 \\
\hline 8 & U.S.A & 3.32 \\
\hline 9 & Guatemala & 2.49 \\
\hline 10 & Indonesia & 2.45 \\
\hline
\end{tabular}

Source: ISO Sugar Year Book 2011 data 2010

According to Friedman et al. (2011) farming community heavyly depends on sugarcane production as it considered to be one of the main cash crop of pakistan and serves as the source of its earnings and provides employment to masses during the whole year. Many industries producing consumable items around the globe depends on sugarcane as it provides raw material for the production of various items like paper, gur, sugar beverages, molasses, and alcohol etc. In addition, it also provides raw materials to many other industries like paints, detergents, chemicals, synthetics, plastics and fiber etc. However, the continous increase in prices of cosumer items everywhere around the world especially in developing countries like Pakistan has caused severe problems to economic growth and purchasing power of individuals ultimately causing food crisis in the country. Pakistan has faced sugar shortage several times due to many factors which causes tremedeous hike in food prices in the country badly damaging consumer purchasing power in the country. Gupta, 1998 indicated in context of India that food crisis is not all the time natural and is mostly caused artifically by factory owners and producers to hike the prices of the commodity for huge profits.

In Pakistan, sugar sector comprises of 81 sugar mills having crushing capacity of approx 6.1 million tons annually which makes the sugar sector the 2nd largest agro based sector of Pakistan. From farming of sugarcane stage to production of sugar, the government earns approx PKR 12.16 Billion annually in the form of different taxes and levies (Pakistan Economic Survey 2009-10). The share of sugar industry in Gross Domestic Product (GDP) is $1.9 \%$, provides 1.5 million employment (directly \& indirectly) and brings about an investment of Rs. 100 billion (Approx). 
Table 2

Top 10 World's Sugar Producers (Raw value in million metric tonnes)

\begin{tabular}{|c|l|c|}
\hline 1 & Brazil & 39.45 \\
\hline 2 & India & 21.15 \\
\hline 3 & EU-27 & 16.76 \\
\hline 4 & China & 11.60 \\
\hline 5 & U.S.A & 7.64 \\
\hline 6 & Thailand & 6.77 \\
\hline 7 & Mexico & 5.08 \\
\hline $\mathbf{8}$ & Pakistan & $\mathbf{3 . 8 6}$ \\
\hline 9 & Australia & 3.63 \\
\hline 10 & Russian Fed. & 2.97 \\
\hline
\end{tabular}

Source: ISO Sugar Year Book 2011 data 2010

However, during last couple of years, the sugar industry in Pakistan has faced many problems and experienced uncertainties which have affected its production and output on producer side whereas price hike and decrease in purchasing power on consumer side. Reasons for this crisis can be attributed to poor government policies and personal interests of few politicians in the government who owned numerous sugar mills in the country. Around the world, the increasing prices of commodities including sugar has worsened state of poverty and further limited human development in many developing countries. Pakistan, like many other developing countries, is a victim of the crisis of rising food prices.

So main aim of this study is:

1 To determine the impact of increasing sugar prices on its consumption and on the profits of sugar industry in Pakistan.

2 To analyze the relationship between price hike and sugar consumption of citizens of Pakistan.

3 To analyze the relationship between purchasing power and sugar consumption of Pakistan.

4 A comparative analysis of the sugar mills to evaluate their profit with increasing sugar prices.

5 To draw conclusion on the sugar consumption pattern and growing profits of sugar companies in Pakistan.

6 To suggest measures for sugar prices control and policies along with to control the unjust profit earn by sugar mills in Pakistan.

\subsection{Hypotheses}

$\mathbf{H}_{1}$ : There is a significant relationship between price hike and sugar consumption.

$\mathbf{H}_{2}$ : $\quad$ Purchasing power has significant impact on the sugar consumption in Pakistan.

\subsection{Conceptual Framework}

In linear equation model the variables are as follows:

$$
S C=\alpha+\beta_{1}(P H)+\beta_{2}(P P)+\varepsilon i
$$




$\begin{array}{lll}\text { Whereas: } & \\ \text { SC } & = & \text { Sugar Consumption } \\ \text { PH } & = & \text { Price Hike } \\ \text { PP } & = & \text { Purchasing Power } \\ \varepsilon & = & \text { Error Term }\end{array}$

\section{Conceptual Framework Diagram}

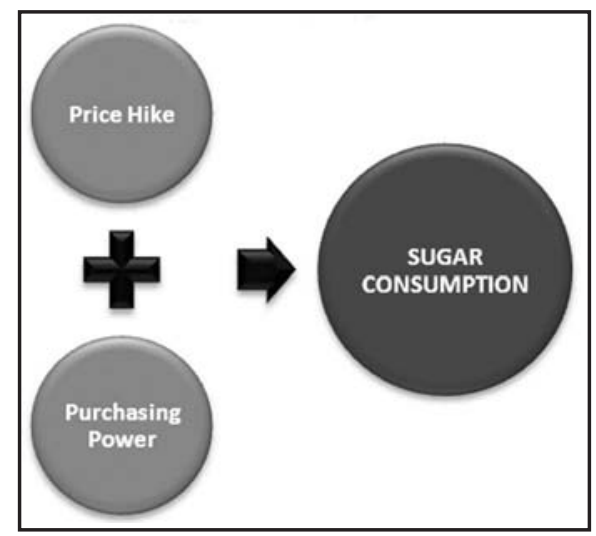

Independent Variable $\rightarrow$ Price Hike and Purchasing Power Dependent Variable $\rightarrow$ Sugar Consumption

\section{LITERATURE REVIEW}

In today's era, Pakistan is stuck with various problems such as lack of proper planning and control, weak institutions, low FDI, energy crisis, food crisis, extremism, poverty and unemployment etc. However, the biggest problem is no one is willing to take any responsibility that they owe towards their country Masood (2012). For any economy the main driving forces are food consumpton and production pattern which play a very essential role in determining the future growth and sustainability of economy. (Chernichovsky \& Meesook, 1984; Goliai \& Pradhan, 2006; Zaman, 2011)

According to Munir et al (2009), Sugarcane is a significant cash crop and plays a vital role in the economic boost up of the growers in whole Pakistan. Sugar is considered as an essential and basic commodity by consumers everywhere in the world. Due to low sugarcane yield per hectare Khushk et al (2011) tagged Pakistan's sugar industry as uncompetitive in nature. On the other hand, cultivators pointed out that sugar crisis is not a natural crisis rather it is all created artificially by mill owners by not purchasing available sugarcane stock from the market. Hence, they concluded that sugar industry in not uncompetitive and there are only two reasons for such crisis. One is to keep sugarcane prices below its support price and secondly to earn undue high profits by the sugar mill owners.

Gupta (1998) also stated something similar. He tried to explain how the state institutions have been monopolized by big farmers that mediate between growers and sugar mills and how the land lords and sugar mill owners are involved in corrupt practices with the intention to enhance their access to more profitable marketing channels. Moreover, the same point of view is also elaborated by M. Ravallion \& M. Lokshin (2000) and Haq et al, (2008) that sugar has become a scarce commodity and which is, in fact, not due to artificial shortage of sugar rather intentionally created by sugar mill owners to earn high profits 


\subsection{Sugar Consumption Pattern}

The obsession for sweets and sugar consumption is very high in Asian countries including Pakistan (Haq et al, 2008). Same is view of Zaman (2011) who says that statistical data in Pakistan shows that per capita consumption of sugar alongwith the overall calorie intake is increasing constantly. The results given by USDA Pakistan Annual Sugar Report showed clearly that the total per capita consumption of refined sugar in Pakistan is approx $25 \mathrm{~kg}$ per individual which is very high compared to other Asian countries like India where per capita consumption of sugar is $14 \mathrm{~kg}$ per inidividual per year, China with $11 \mathrm{~kg}$ per individual and Bangladesh with only just $10 \mathrm{~kg}$ per individual.

According to Pakistan Economic Survey (2009-10), intake of per capita calorie in Pakistan has grown dramatically in the last four decades from 1750 kilos to 2450 Kilos calories which showed an average growth rate of $0.90 \%$. However, despite this, $20 \%$ population of Pakistan is still undernourished. In the last 15 years, sugar consumption in Pakistan has arisen from 2.89 million in 1999-00 to 3.96 million tons in 2009-10 which is clearly indicative of increasing trend in sugar consumption. The main reason behind it is in the increase in total population of Pakistan whereas actual sugar consumption has decreased due to increase in sugar crises and decreasing purchasing power of individuals, among other reasons.

\section{2- Sugar Crisis -- a Myth and Reality}

Food crisis in any country including Pakistan happens due to shortage of supply in the market Khan (1997), and the reasons for sugar crisis are not much different. Shortage of supply in the market may be natural or artificial. Natural shortage includes unfavorable weather conditions, adverse structure of market that ultimately decreases the production over a time period, and changes in government policies that might affect the production. However, artificial shortfall occurs by deliberate hoarding of goods to create shortage for undue profits Haq et al, (2008). It frequently happens in Pakistan especially during the month of Holy Ramadan that sugar crisis is created deliberately by the mill owners and distributors with a motive to maximize the rates of sugar for unjust profits. Trade Corporation of Pakistan (TCP) has stated that Government of Pakistan imposed export ban of sugar and import duty has been waived in an attempt to revert the impact of sugar crisis but sugar hoarding with an intention to raise prices is going on.

\section{RESEARCH METHODOLOGY}

Since objective of this research work is to gain a deeper understanding of the sugar consumption pattern and growing profitability of sugar industry in Pakistan, an explanatory style of study was preferred. This helps readers identify the connection between sugar consumption pattern of individuals and the growing profits of sugar mills in Pakistan. Questionnaire was designed to collect the data from 240 individuals - the sugar consumers. Secondary data in the form of Financial Statements of 3 sugar mills; Mehran Sugar Mills, Kohinoor Sugar Mills and Chashma Sugar Mills were also gathered to analyze their profitability.

\section{DATA ANALYSIS}

Regression, Correlation and ANOVA were used to analyze data for this study as the research is merely based on statistical analyses. 


\subsection{Regression Analysis}

Table 4

Model Summary

\begin{tabular}{|c|c|c|c|c|}
\hline Model & R & R Square & Adjusted R Square & Std. Error of the Estimate \\
\hline 1 & $0.303^{\mathrm{a}}$ & 0.092 & 0.084 & .79361 \\
\hline \multicolumn{4}{|l}{ a. Predictors: (Constant), PurchasingPower, PriceHike } \\
\hline
\end{tabular}

In the model summary table 4 , the value " $\mathrm{R}$ " is $\mathbf{0 . 3 0 3}$ which indicate that there is positive correlation (linear relationship) between Sugar Consumption and Purchasing Power and Price Hike. In the second column "R Square" is explained which is $\mathbf{9 . 2 \%}$ of variation in Sugar Consumption is caused by predictors. Third column is "Adjusted $\mathrm{R}$ square" is $\mathbf{8 . 4 \%}$ explaining variation is caused by predictors considering number of observations and the number of predicted variables.

\subsection{Analysis of Variance (ANOVA)}

Table 5

ANOVAb

\begin{tabular}{|l|c|c|c|c|c|c|}
\hline \multicolumn{2}{|c|}{ Model } & Sum of Squares & Df & Mean Square & F & Sig. \\
\hline \multirow{3}{*}{1} & Regression & 15.118 & 2 & 7.559 & 12.002 & $0.000^{\text {a }}$ \\
\cline { 2 - 7 } & Residual & 149.266 & 237 & .630 & & \\
\cline { 2 - 7 } & Total & 164.385 & 239 & & & \\
\hline
\end{tabular}

In table 5, the results of ANOVA test shows that $F<0.05$ i.e. Significance value of $\mathbf{F}=\mathbf{0 . 0 0 0}$ which reveals that the research model is acceptable and deviation in the model is not just by chance.

\subsection{Coefficient Analysis}

Table 6

Coefficientsa

\begin{tabular}{|c|l|c|c|c|c|c|}
\hline \multirow{2}{*}{ Model } & \multicolumn{2}{|c|}{$\begin{array}{c}\text { Unstandardized } \\
\text { Coefficients }\end{array}$} & $\begin{array}{c}\text { Standardized } \\
\text { Coefficients }\end{array}$ & \multirow{2}{*}{ T } & \multirow{2}{*}{ Sig. } \\
\cline { 3 - 5 } \multicolumn{2}{|c|}{} & B & Std. Error & Beta & & \\
\hline \multirow{3}{*}{1} & (Constant) & 2.571 & 0.326 & & 7.887 & 0.000 \\
\cline { 2 - 7 } & PriceHike & 0.372 & 0.084 & 0.308 & 4.413 & 0.000 \\
\cline { 2 - 7 } & PurchasingPower & -0.011 & 0.079 & -0.010 & -0.141 & 0.888 \\
\hline \multicolumn{2}{|l|}{ a. Dependent Variable: SugarConsumption } \\
\hline
\end{tabular}

In above table 6 , firstly the value of constant is 2.571 which indicate that if independent variable will be zero, sugar consumption will be 2.571 . Secondly, P-value of constant is less than 0.05 which shows its significance. Furthermore, the first independent variable showed significance with sugar consumption as its P-value is less than 0.05 and $\mathrm{t}$-value is 4.413 . The beta value for Price Hike is 0.372 which shows that if Price Hike 
changes by 1 million it will bring 0.372 million change in Sugar Consumption. Hence, there is relationship between price hike and sugar consumption in Pakistan.

Equation for this relationship is:

\section{Sugar Consumption $=\mathbf{2 . 5 7 1 + 0 . 3 7 2 P H}$}

Where, $\mathrm{PH}$ is Price Hike

Second independent variable, Purchasing Power depicts insignificant relationship as its $\mathrm{P}$-value is 0.888 and $\mathrm{t}$-value is -0.141 . Its beta value shows 1 million changes in purchasing power will bring -0.011 million change in profitability. Hence, Purchasing power has a negative impact on sugar consumption in Pakistan.

Equation for this relationship is:

Sugar Consumption $=$ 2.571-0.011PP

Where, PP is Purchasing Power

\subsection{Correlation Analysis}

Table 7

Correlations Matrix

\begin{tabular}{|c|c|c|c|c|}
\hline & & $\begin{array}{c}\text { Sugar } \\
\text { Consumption }\end{array}$ & Price Hike & $\begin{array}{c}\text { Purchasing } \\
\text { Power }\end{array}$ \\
\hline \multirow{3}{*}{$\begin{array}{c}\text { Sugar } \\
\text { Consumption }\end{array}$} & Pearson Correlation & 1 & $0.303 * *$ & $0.132 *$ \\
\hline & Sig. (2-tailed) & & 0.000 & 0.041 \\
\hline & $\mathrm{N}$ & 240 & 240 & 240 \\
\hline \multirow{3}{*}{ Price Hike } & Pearson Correlation & $0.303 * *$ & 1 & $0.460 * *$ \\
\hline & Sig. (2-tailed) & 0.000 & & 0.000 \\
\hline & $\mathrm{N}$ & 240 & 240 & 240 \\
\hline \multirow{3}{*}{$\begin{array}{c}\text { Purchasing } \\
\text { Power }\end{array}$} & Pearson Correlation & $0.132 *$ & $0.460 * *$ & 1 \\
\hline & Sig. (2-tailed) & 0.041 & 0.000 & \\
\hline & $\mathrm{N}$ & 240 & 240 & 240 \\
\hline
\end{tabular}

On the basis of Correlation Matrix table 7, the independent variable $\mathbf{R}=\mathbf{0 . 3 0 3}$ which is clearly showing a positive correlation between Price Hike and Sugar Consumption. On the other hand, Purchasing Power $\mathbf{R}=\mathbf{0 . 1 3 2}$ is close to zero that means there is low correlation between purchasing power and sugar consumption.

\subsection{Financial Statements Analysis}

\subsubsection{Measures of Profitability}

\section{i. Gross Profit Ratio}




\begin{tabular}{|c|c|c|c|c|c|}
\hline \multicolumn{2}{|c|}{$\begin{array}{c}\text { Kohinoor Sugar Mills Ltd } \\
\text { (Punjab) }\end{array}$} & \multicolumn{2}{|c|}{$\begin{array}{c}\text { Mehran Sugar Mills Ltd } \\
\text { (Sindh) }\end{array}$} & $\begin{array}{c}\text { Chashma Sugar Mills Ltd } \\
\text { (NWFP) }\end{array}$ \\
\hline $\mathbf{2 0 1 1}$ & $\mathbf{2 0 1 0}$ & $\mathbf{2 0 1 1}$ & $\mathbf{2 0 1 0}$ & $\mathbf{2 0 1 1}$ & $\mathbf{2 0 1 0}$ \\
\hline $8.64 \%$ & $1.90 \%$ & $13.35 \%$ & $12.36 \%$ & $13.54 \%$ & $12.03 \%$ \\
\hline
\end{tabular}

\section{Gross Profit Rate}

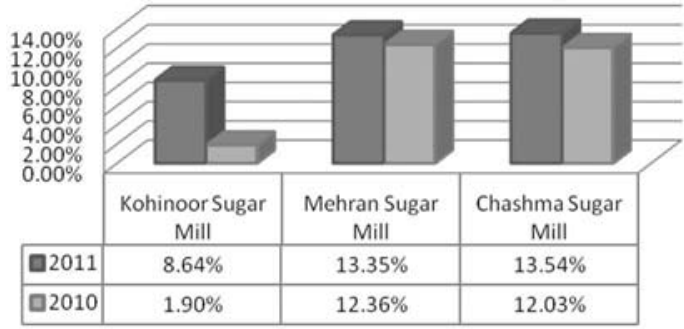

From the above gross profit analysis of all three sugar mills it is clear that gross profit rate has increased from 2010 to 2011 indicating enhancement in profit. In fact, Kohinoor Sugar Mills gross profit has shown tremendously increase i.e. 355\% compare to previous year.

\section{ii. Operating Expense Ratio}

\begin{tabular}{|c|c|c|c|c|c|}
\hline \multicolumn{2}{|c|}{$\begin{array}{c}\text { Kohinoor Sugar Mills Ltd } \\
\text { (Punjab) }\end{array}$} & \multicolumn{2}{|c|}{$\begin{array}{c}\text { Mehran Sugar Mills Ltd } \\
\text { (Sindh) }\end{array}$} & $\begin{array}{c}\text { Chashma Sugar Mills Ltd } \\
\text { (NWFP) }\end{array}$ \\
\hline $\mathbf{2 0 1 1}$ & $\mathbf{2 0 1 0}$ & $\mathbf{2 0 1 1}$ & $\mathbf{2 0 1 0}$ & $\mathbf{2 0 1 1}$ & $\mathbf{2 0 1 0}$ \\
\hline 0.048 & 0.051 & 0.016 & 0.021 & 0.014 & 0018 \\
\hline
\end{tabular}

Operating Expense Ratio

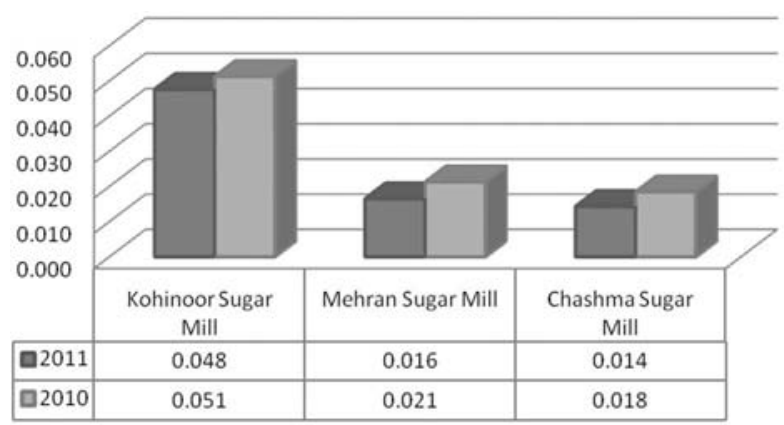

In the above analysis of Kohinoor, Mehran and Chashma sugar mills, it is revealed that the operating expense ratio has decreased i.e. $-7.17 \%,-22.50 \%,-22.47 \%$ respectively in compared to the previous year which eventually will increase the profits of the sugar mills. 


\section{iii. Operating Income}

\begin{tabular}{|c|c|c|c|c|c|}
\hline $\begin{array}{c}\text { Kohinoor Sugar Mills Ltd } \\
\text { (Punjab) }\end{array}$ & \multicolumn{2}{|c|}{$\begin{array}{c}\text { Mehran Sugar Mills Ltd } \\
\text { (Sindh) }\end{array}$} & \multicolumn{2}{c|}{$\begin{array}{c}\text { Chashma Sugar Mills Ltd } \\
\text { (NWFP) }\end{array}$} \\
\hline $\mathbf{2 0 1 1}$ & $\mathbf{2 0 1 0}$ & $\mathbf{2 0 1 1}$ & $\mathbf{2 0 1 0}$ & $\mathbf{2 0 1 1}$ & $\mathbf{2 0 1 0}$ \\
\hline $63,658,693.00$ & $-44,648,227.00$ & $509,613,049.00$ & $393,081,736.00$ & $712,225.00$ & $647,940.00$ \\
\hline
\end{tabular}

\section{Operating Income}

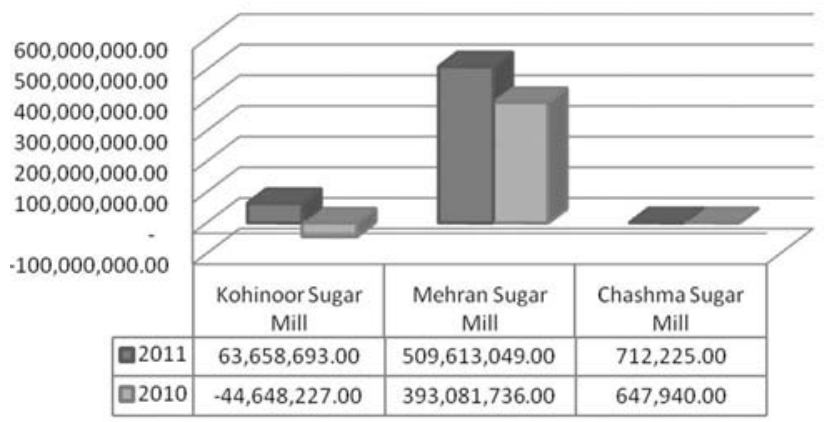

Operating income depicts the profits of sugar mills in Pakistan. In the above table, it is clearly shown that the net profits of all three sugar mills have increased in respect of previous year.

\section{iv. Net Income as Percentage of Net Sales}

\begin{tabular}{|c|c|c|c|c|c|}
\hline $\begin{array}{c}\text { Kohinoor Sugar Mills Ltd } \\
\text { (Punjab) }\end{array}$ & \multicolumn{2}{|c|}{$\begin{array}{c}\text { Mehran Sugar Mills Ltd } \\
\text { (Sindh) }\end{array}$} & $\begin{array}{c}\text { Chashma Sugar Mills Ltd } \\
\text { (NWFP) }\end{array}$ \\
\hline $\mathbf{2 0 1 1}$ & $\mathbf{2 0 1 0}$ & $\mathbf{2 0 1 1}$ & $\mathbf{2 0 1 0}$ & $\mathbf{2 0 1 1}$ & $\mathbf{2 0 1 0}$ \\
\hline$-2.72 \%$ & $-8.20 \%$ & $9.56 \%$ & $-8.36 \%$ & $2.81 \%$ & $5.47 \%$ \\
\hline
\end{tabular}

Net Income as Percentage of Net Sales

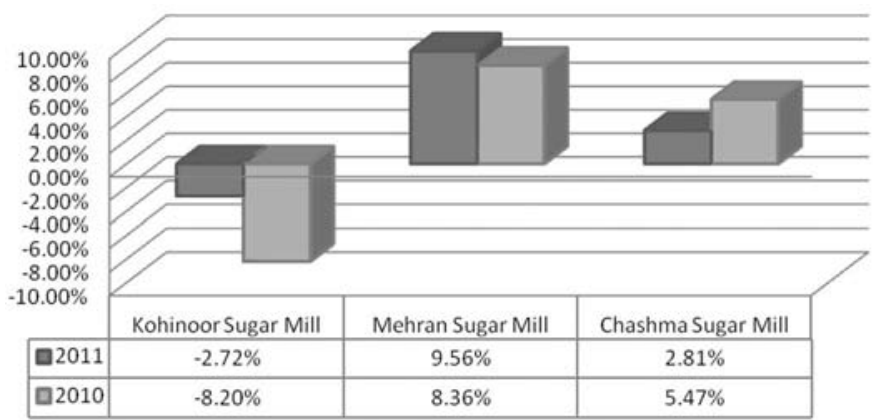

The above graph elaborates that Kohinoor and Mehran sugar mills profit has increase (loss decrease) in comparison to last year. However, the results of Chashma sugar mills are totally inverse than the other two mills evaluated in this study. 


\subsubsection{Measures of Financial Leverages}

\section{i. Debt Ratio}

\begin{tabular}{|c|c|c|c|c|c|}
\hline $\begin{array}{c}\text { Kohinoor Sugar Mills Ltd } \\
\text { (Punjab) }\end{array}$ & \multicolumn{2}{|c|}{$\begin{array}{c}\text { Mehran Sugar Mills Ltd } \\
\text { (Sindh) }\end{array}$} & $\begin{array}{c}\text { Chashma Sugar Mills Ltd } \\
\text { (NWFP) }\end{array}$ \\
\hline $\mathbf{2 0 1 1}$ & $\mathbf{2 0 1 0}$ & $\mathbf{2 0 1 1}$ & $\mathbf{2 0 1 0}$ & $\mathbf{2 0 1 1}$ & $\mathbf{2 0 1 0}$ \\
\hline 0.78 & 0.71 & 0.75 & 0.70 & 0.71 & 0.68 \\
\hline
\end{tabular}

\section{Debt Ratio}

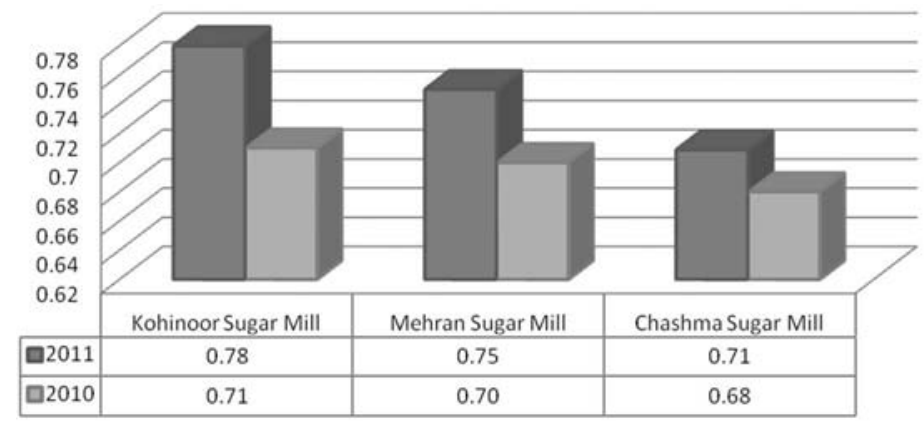

In the schedule we can see that debt ratio of all firms is increasing indicating higher share of creditors on one side and enhancement in investment and ultimately profit on the other side.

\section{ii. Debt to Equity Ratio}

\begin{tabular}{|c|c|c|c|c|c|}
\hline $\begin{array}{c}\text { Kohinoor Sugar Mills Ltd } \\
\text { (Punjab) }\end{array}$ & \multicolumn{2}{|c|}{$\begin{array}{c}\text { Mehran Sugar Mills Ltd } \\
\text { (Sindh) }\end{array}$} & $\begin{array}{c}\text { Chashma Sugar Mills Ltd } \\
\text { (NWFP) }\end{array}$ \\
\hline $\mathbf{2 0 1 1}$ & $\mathbf{2 0 1 0}$ & $\mathbf{2 0 1 1}$ & $\mathbf{2 0 1 0}$ & $\mathbf{2 0 1 1}$ & $\mathbf{2 0 1 0}$ \\
\hline 3.56 & 2.47 & 2.93 & 2.32 & 2.43 & 2.12 \\
\hline
\end{tabular}

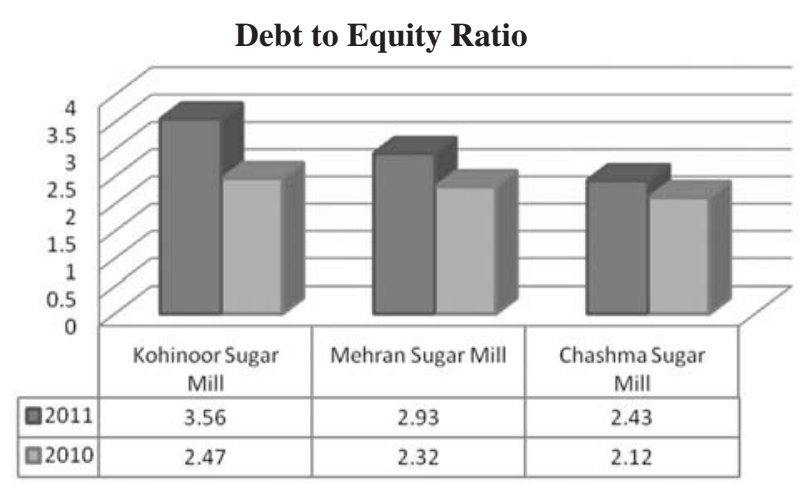

Results for debt to equity ratio for all three sugar mills show an increasing trend in comparison to previous year, in the result, all the sugar mills are with high leverage. 


\subsection{Measures of Earnings}

\section{i. Return on Assets (ROA)}

\begin{tabular}{|c|c|c|c|c|c|}
\hline $\begin{array}{c}\text { Kohinoor Sugar Mills Ltd } \\
\text { (Punjab) }\end{array}$ & \multicolumn{2}{|c|}{$\begin{array}{c}\text { Mehran Sugar Mills Ltd } \\
\text { (Sindh) }\end{array}$} & $\begin{array}{c}\text { Chashma Sugar Mills Ltd } \\
\text { (NWFP) }\end{array}$ \\
\hline $\mathbf{2 0 1 1}$ & $\mathbf{2 0 1 0}$ & $\mathbf{2 0 1 1}$ & $\mathbf{2 0 1 0}$ & $\mathbf{2 0 1 1}$ & $\mathbf{2 0 1 0}$ \\
\hline$-1.95 \%$ & $-5.52 \%$ & $17.15 \%$ & $21.24 \%$ & $3.84 \%$ & $10.68 \%$ \\
\hline
\end{tabular}

\section{Return on Assets (ROA)}

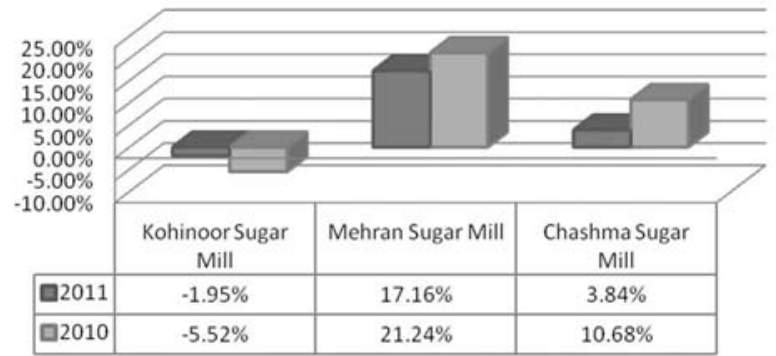

As per above results, Return on Assets (ROA) for 2011 is $-1.95 \%, 17.16 \%$ and $3.84 \%$ for Kohinoor, Mehran and Chashma sugar mills respectively.

\section{ii. Return on Equity (ROE)}

\begin{tabular}{|c|c|c|c|c|c|}
\hline $\begin{array}{c}\text { Kohinoor Sugar Mills Ltd } \\
\text { (Punjab) }\end{array}$ & \multicolumn{2}{c|}{$\begin{array}{c}\text { Mehran Sugar Mills Ltd } \\
\text { (Sindh) }\end{array}$} & $\begin{array}{c}\text { Chashma Sugar Mills Ltd } \\
\text { (NWFP) }\end{array}$ \\
\hline $\mathbf{2 0 1 1}$ & $\mathbf{2 0 1 0}$ & $\mathbf{2 0 1 1}$ & $\mathbf{2 0 1 0}$ & $\mathbf{2 0 1 1}$ & $\mathbf{2 0 1 0}$ \\
\hline$-7.78 \%$ & $-18.49 \%$ & $63.33 \%$ & $72.94 \%$ & $12.73 \%$ & $43.50 \%$ \\
\hline
\end{tabular}

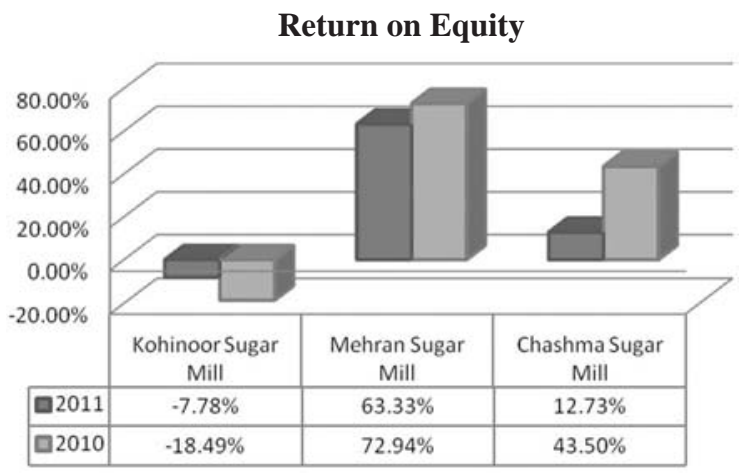

From the above table it can been seen that in case of Mehran Sugar Mill, there is an increase in profit with the increase in equity and incase of Kohinoor Sugar Mill there in decrease in loss with increase in equity. Both the situations forecast healthy sign for companies. On the other hand, Chashma Sugar Mill showed an increase in owner equity with decrease in net income which is negative for the company. 
iii. Earnings per Share (EPS)

\begin{tabular}{|c|c|c|c|c|c|}
\hline \multicolumn{2}{|c|}{$\begin{array}{c}\text { Kohinoor Sugar Mills Ltd } \\
\text { (Punjab) }\end{array}$} & \multicolumn{2}{c|}{$\begin{array}{c}\text { Mehran Sugar Mills Ltd } \\
\text { (Sindh) }\end{array}$} & \multicolumn{2}{c|}{$\begin{array}{c}\text { Chashma Sugar Mills Ltd } \\
\text { (NWFP) }\end{array}$} \\
\hline $\mathbf{2 0 1 1}$ & $\mathbf{2 0 1 0}$ & $\mathbf{2 0 1 1}$ & $\mathbf{2 0 1 0}$ & $\mathbf{2 0 1 1}$ & $\mathbf{2 0 1 0}$ \\
\hline-4.75 & -6.78 & 18.67 & 16.93 & 4.90 & 10.78 \\
\hline
\end{tabular}

Return on Equity

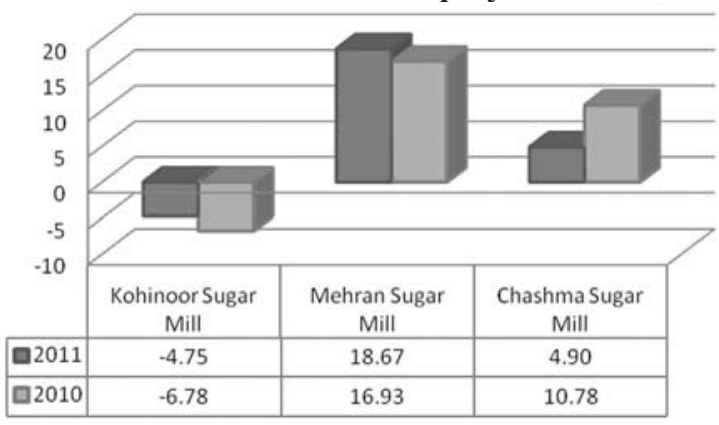

From above table, in case of Mehran and Kohinoor Sugar Mills there is an increase in EPS compare to last year which is healthy sign and financial stability of firms. On the other hand, Chashma Sugar Mill showed a decrease EPS for the year which is negative for the company.

\subsection{Conclusion of Financial Analysis}

It is concluded from the financial analysis of three sugar mills of three different provinces of Pakistan that all three sugar mills were generating good amount of profits and expanding their business with time.

\section{CONCLUSION}

The study was conducted with the main objective of evaluating the impact of rising sugar prices on consumption pattern of individuals and on growing profits of sugar mills in Pakistan. Results of the study illustrate that individuals in Pakistan have decreased their sugar consumption due to increasing prices.

As per analyzed data of 240 respondent revels that ,the disturbed purchasing power due to total inflation and continues price hiking of sugar is affecting the sugar consumption of individuals from excessive consumption to necessitate based consumption. The patterns of sugar consumption on individual bases are changing towards conservative patterns due to price hiking (Khan, 1997). Patterns of sugar consumption on individual bases are also changing towards conservative patterns due to price hike. In Pakistan, alternative sweeteners like saccharin are seldom used owing to their unhealthy image among the public.

On the other hand, it was found that three sugar mills part of this research work were earning huge profits. It was that all sugar mills were running in stable condition with self favored terms and conditions with low production cost in comparison of imposed price hiking in market and taking benefits of low production cost and from artificial sugar price raising that ultimately leading the high profit generation.

\section{RECOMMENDATIONS}

The regulatory bodies should tighten control over the sugar industry of Pakistan 
to meet the domestic demand and control the price of sugar that artificially and continuously increasing. The precise recommendations are:

1. Sugar consumption level and demand in Pakistan is continuously increasing with the growth rate of population, sugar production should be increased accordingly. Shortage of supply is more likely to cause price hike and further hoarding.

2. There should be awareness of sugar alternatives with clinical approval and conformed health safety parameters, so the population of Pakistan can switch to the other sweeteners, positive image building should be firm for smooth shifting of alternative calories source.

3. Price of sugar should be scheduled separately with strict compliance of its domestic and commercial utilization.

4. In order to prevent hoarding, regulatory authorities should make and implement rigorous policies and should ensure that the sugar mill owners do not enter into cartel making or indulge in other illegal and unethical tactics.

5. Independent forecasting of the sugar demand involving the private sector should be made and all necessary measures should be taken to overcome the problem of sugar shortage in the country by timely importing sugar when needed.

\section{REFERENCES}

1. Chernichovsky, D., \& Meesook, A. (1984). Pattrens of Food Consumption and Nutrition in Indonesia. The World Bank Washington, DC Tecnical Paper No. 670.

2. Friedman, J., Hong, S. Y., \& Hou, X. (November 2011). The Impact of The Food Price Crisis on Consumption and Caloric Availability in Pakistan. Healt, Nutrition and Population (HNP) Discussion Paper

3. Goliai, R., \& Pradhan, C. N. (2006). Changing Food Consumption Pattern in Rural India: Implication of Food and Nutrition Security. Indian Journal of Agricultural Economics, Indian Society of Agricultural Economics Mumbai Vol. 61 No. 3.

4. Govt of Pakistan, E. S.-1. (2010). Pakistan Economic Survey 2009-10. Islamabad: Government of Pakistan Finance Division Economic Adviser Wing.

5. Gupta, A. (1998). Postcolonial developments: Agriculture in the Making. Dhurham, North Carolina; London: Duke University.

6. Haq, Z. U., Nazli, H., \& Meilke, K. (2008). Implications of high food prices for poverty in Pakistan. Agricutural Economics 39, 477 - 484.

7. Khan, M. H. (Winter 1997). Agricultural 'Crisis' In Pakistan: Some explanations and Policy Options. The Pakistan Development Review 36:4 Part 1, 419-466.

8. Khushk, A. M., Memon, A., \& Saeed, I. (2011). Analysis Of Sugar Industry Competitiveness In Pakistan. J. Agric. Res., 49(1).

9. Masood, M. T. (March 2012). Dilemma of Third World Countries - Problems Facing Pakistan Energy Crisis a Case-in-Point. International Journal of Business and Management Vol. 7, No. 5.

10. M. Ravallion, M. Lokshin (2000), Who wants to redistribute? The tunnel effect in 1990s Russia. Journal of Public Economics 76 (2000) 87 -104

11. Munir, M. A., Zafar, M., Yasin, M., Iqbal, J., \& Cheema, M. S. (2009). Qualitative and Quantitative Characteristics of Some Autumn Sown Promising Sugarcane Varities. Pakistan Sugar Journal, Vol XXIV, No. 04, 9-12.

12. Zaman, K. U. (May 2011). Food Production and Consumption Pattern in Pakistan During 1979-80 to 2009-10. Mediterranean Journal of Social Sciences Vol.2. 